\title{
拢萃
}

\section{5. 米國電燈協會電球委員會報告}

$$
\text { (一九二四年度) }
$$

電球䆙上高 一九二三年度に於ける電球瀆上總數は $243,000,000$ 個にして前年に 比し $2 \frac{1}{2} \%$ を增加し新記錄を作つれ。一九○七年以降の本均に就て言へば、逐全 增加率は電球數に於て $10 \%$ 、其光力數に於て $20 \%$ である。而して一九二三年の數 字は一九○七年に對し電球數に於て四倍、光力數に於て約一五倍の增加である。

平均ルーメン數、消費電力及能究 電球數と光力數との逐年の增加を見るに、前

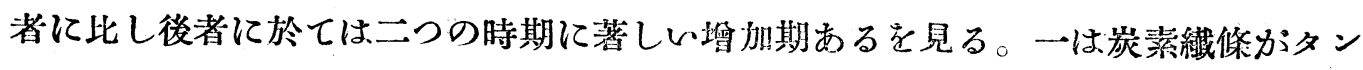
グスラン纎條に變つれ時であり、最近に至つては虑斯充填電球の普及による䉆であ る(第一表參照)。

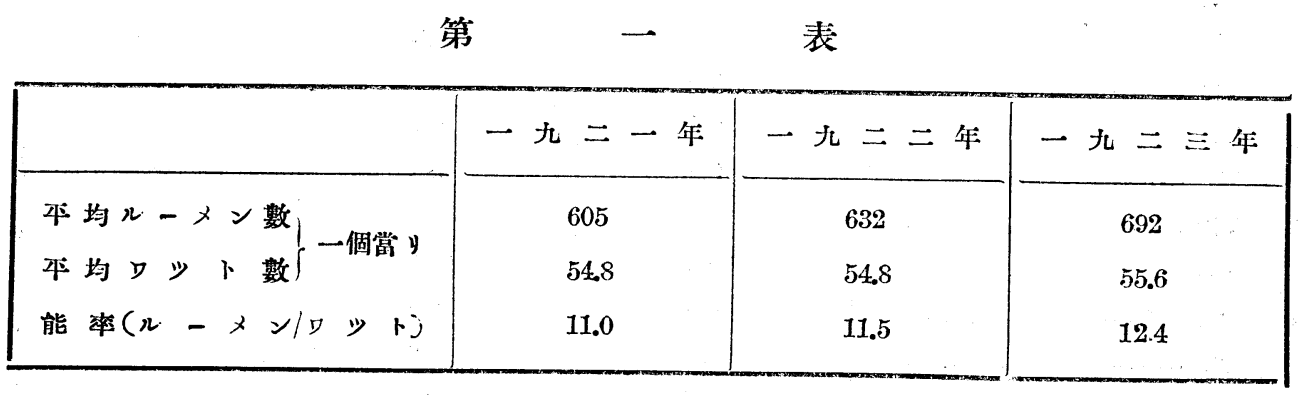

使用電涯別電球數 一一五ヴオルト用電球は逐年䝬加し、三三○反一○ヴオル ト用が次第に減少する倾向を有す。即一一五がオルトを標準電力と淡へ、上下ヴオ ルト宛の公差を許して一一○一二○ヴオルトの三種の電壓用電球に就て見るに一 九二三年は前年に比し其數を $91.5 \%$ よ $92.6 \%$ 亿增加しれ。(第二表区第三表參 照)

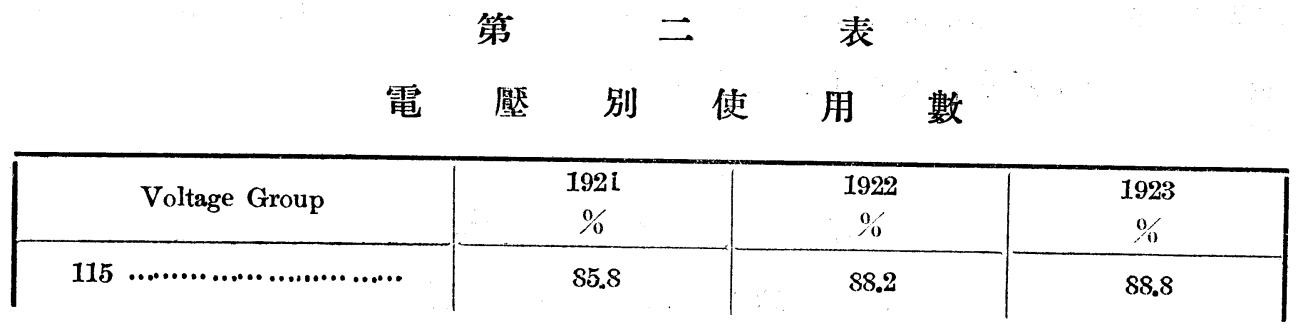




\begin{tabular}{|c|c|c|c|}
\hline (............................... & 4.3 & 4.0 & 3.9 \\
\hline Street Series & 1.9 & 1.4 & 1.6 \\
\hline 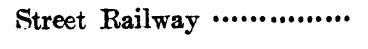 & $\mathbf{2 . 6}$ & $\mathbf{2 . 0}$ & 3.3 \\
\hline 30 and 60 & 4.7 & 3.5 & 2.2 \\
\hline Miscellaueous & 0.7 & 0.9 & 1.2 \\
\hline Total & 100.0 & 100.0 & 100.0 \\
\hline \multirow{2}{*}{\multicolumn{4}{|c|}{ 110ー130 ヴオルト用電球の細目電壓別 }} \\
\hline & & & \\
\hline & $\begin{array}{c}1921 \\
\% \\
\end{array}$ & $\begin{array}{c}1922 \\
\% \\
\end{array}$ & $\begin{array}{c}1923 \\
\% \\
\end{array}$ \\
\hline \multirow{16}{*}{$\begin{array}{l}110 \\
110 \\
111 \\
112 \ldots \ldots \ldots \ldots \ldots \ldots \ldots \ldots \\
113 \\
114\end{array}$} & 0.4 & 0.4 & 0.5 \\
\hline & 28.1 & 263 & 22.9 \\
\hline & 一 & - & - \\
\hline & 3.1 & 1.3 & 0.4 \\
\hline & 1.0 & - & - \\
\hline & 0.5 & - & - \\
\hline & 35.5 & 39.3 & 42.8 \\
\hline & 0.5 & 一 & - \\
\hline & 0.1 & 0.1 & 0.3 \\
\hline & 0.9 & 0.4 & 0.3 \\
\hline & - & - & 一 \\
\hline & 23.6 & 25.9 & 26.9 \\
\hline & 0.5 & 0.3 & - \\
\hline & 49 & 5.2 & 5.1 \\
\hline & 0.9 & 0.8 & 0.8 \\
\hline & 100.0 & 100.0 & 100.0 \\
\hline $\begin{array}{l}\text { Total Percentage at } 110 \\
115 \text { and } 120 \text { volts }\end{array}$ & $87 \cdot 2$ & 91.5 & 92.6 \\
\hline
\end{tabular}

電球の大さ別 一九二三年度に於て死斯填充電球の著しい增加を見る。其數に於 一七前年に比し $22.3 \%$ 增加なるも、wattage に於て $48.1 \%$ lumens に於て $58.4 \%$ 音 の增加率なり。真空電球に於ては 25 ワットを最多數とし、死斯充填電球に於ては 75 及 100 ワット最も普及す（第四表窑照）。

第四表

電球大さ别 


\begin{tabular}{|c|c|c|c|}
\hline $\begin{array}{l}\text { Size } \\
\text { Vacuum Type }\end{array}$ & $\begin{array}{c}1921 \\
\%\end{array}$ & $\begin{array}{c}1922 \\
\%\end{array}$ & $\begin{array}{c}1923 \\
\%\end{array}$ \\
\hline 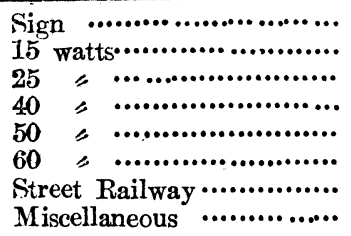 & $\begin{array}{r}6.1 \\
3.5 \\
17.7 \\
20.2 \\
14.7 \\
13.1 \\
2.6 \\
1.5\end{array}$ & $\begin{array}{r}5.7 \\
4.5 \\
18.6 \\
19.3 \\
15.5 \\
12.5 \\
1.2 \\
1.3\end{array}$ & $\begin{array}{r}4.8 \\
5.3 \\
19.9 \\
17.3 \\
16.2 \\
10.9 \\
2.3 \\
1.0\end{array}$ \\
\hline Total Vacuum Type......... & $79 \cdot 4$ & 79.5 & 77.7 \\
\hline Gas Filled Type & $\begin{array}{c}1921 \\
\%\end{array}$ & $\begin{array}{c}1922 \\
\%\end{array}$ & $\begin{array}{c}1923 \\
\%\end{array}$ \\
\hline 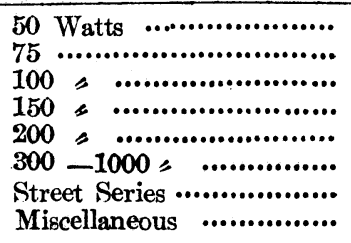 & $\begin{array}{l}1.4 \\
6.6 \\
6.5 \\
0.8 \\
2.2 \\
0.9 \\
1.9 \\
0.3\end{array}$ & $\begin{array}{l}1.5 \\
6.4 \\
6.4 \\
1.3 \\
2.4 \\
0.8 \\
1.4 \\
0.3\end{array}$ & $\begin{array}{l}1.7 \\
6.6 \\
6.9 \\
1.5 \\
2.7 \\
0.9 \\
1.6 \\
0.4\end{array}$ \\
\hline Total Gas Filled Type ... & $20 \cdot 6$ & 20.5 & 22.3 \\
\hline
\end{tabular}

Street Series 電球 一九二二年の本均の大さは 1816 ルーメンにして逐年增加し つ〉あ6（第五表及第六表參照）。

第 五 表

大さ別 Series Lamp 表

\begin{tabular}{|c|c|c|c|}
\hline & $\begin{array}{c}1921 \\
\%\end{array}$ & $\begin{array}{c}1922 \\
\%\end{array}$ & $\begin{array}{c}1923 \\
\%\end{array}$ \\
\hline 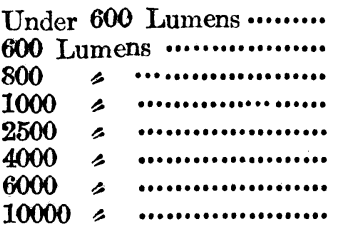 & $\begin{array}{r}13.8 \\
23.9 \\
9.4 \\
26.1 \\
11.8 \\
10.1 \\
4.3 \\
0.6\end{array}$ & $\begin{array}{r}12.4 \\
23.5 \\
9.5 \\
24.6 \\
12.8 \\
10.1 \\
6.4 \\
0.7\end{array}$ & $\begin{array}{r}7.8 \\
20.1 \\
8.6 \\
26.2 \\
15.3 \\
11.9 \\
8.4 \\
1.7\end{array}$ \\
\hline Total & 1000 & 1000 & $100 \cdot 0$ \\
\hline
\end{tabular}

第六表

Ampere 別 Series Lamp 表

\begin{tabular}{|c|c|c|c|}
\hline & $\begin{array}{c}1921 \\
\%\end{array}$ & $\begin{array}{c}1922 \\
\%\end{array}$ & $\begin{array}{c}1923 \\
\%\end{array}$ \\
\hline 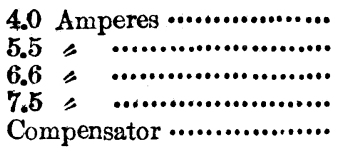 & $\begin{array}{r}9 \cdot 8 \\
8 \cdot 7 \\
61 \cdot 7 \\
11 \cdot 3 \\
8 \cdot 5\end{array}$ & $\begin{array}{r}9.0 \\
7.8 \\
60.9 \\
12.0 \\
10.3\end{array}$ & $\begin{array}{r}7.3 \\
6.3 \\
60.2 \\
12.7 \\
12.5\end{array}$ \\
\hline Total ........................... & 100.0 & 100.0 & 100.0 \\
\hline
\end{tabular}


價格の變動 價格の變動の詳細に就ては圖に示す通りである。マッダ電球に就い て言へば一九二三年五月一日に本均二制の值下げが行はれ、一九二四年二月一日に は、七分五厘の徝下があつて。即一九二二年一月一日以爽四回の值下があ b、其結果 として昔時 40 cents の 10〜50 ワットのものは現今 30 cents 亿、ヌ1弗の 100 ワ ットのもの現今 60 cents になつれ。

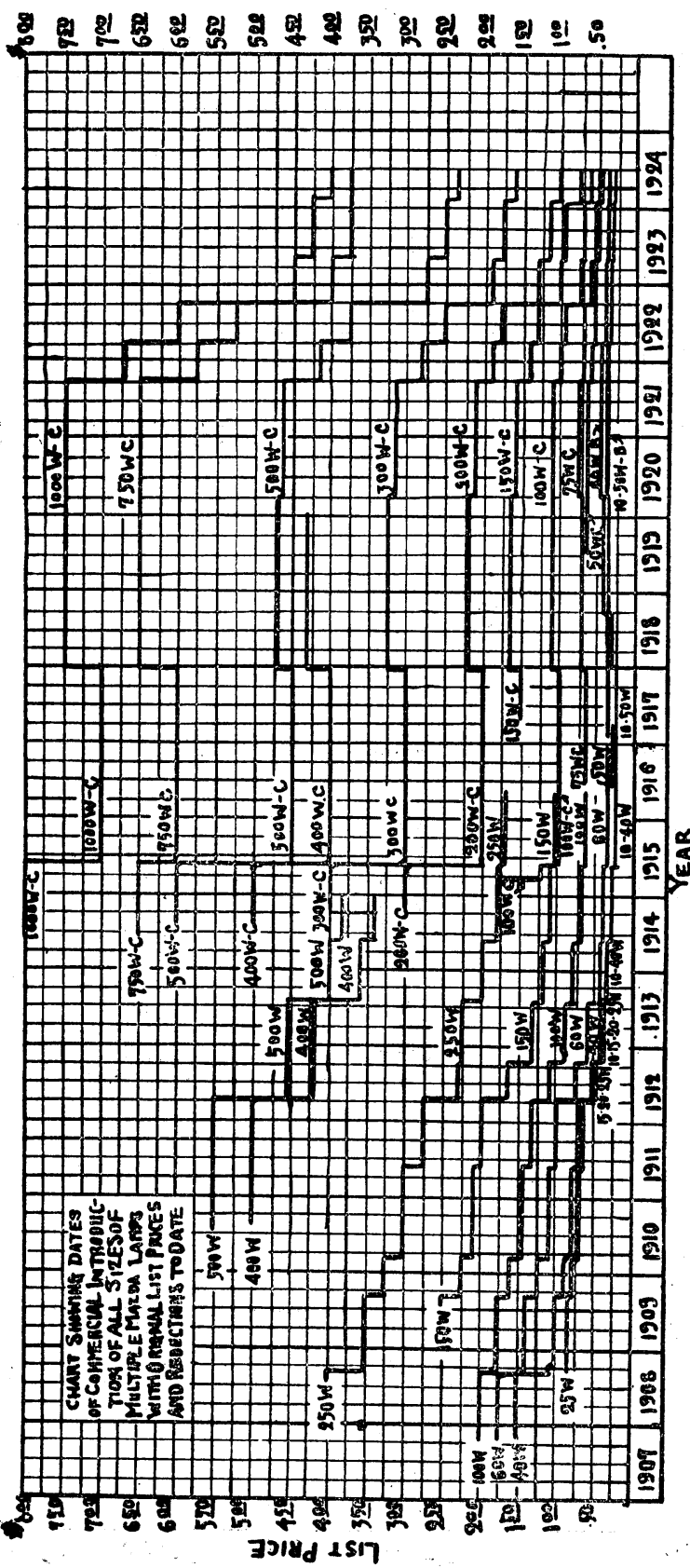

電球製作上の進步 一九二三 年度に於て注目すべさ發達は Tipless I Lamp の工業的生産であ る。白熱電球發明以隶の宿題で 從來も小規模に製造はせられて るれが、製造に件及困難の第に 價格が大であつれ。新しい製造 方法は從來電球製造者に於て不 可能と思惟せられてるれ方法で 全く斯界に於ける革命的性質の ものであるといふ。 即此方法では從來の “Tubulating”法に依らず、排氣硝子 管を wire seal の中に seal し更 に空氮を送つて此排氮管を膨脤 せしむる样な方法であうて、此 製造方法の發達の結果米國に於 ける第一流の會社の製品は現在 では全部 Tipless となつてるる。 倘本報告には一九○七年より 一九二三年の間に於ける各種統 計曲線が揭示せられてるる。 
16. 人眼の「ラヂウム」及びレントゲン線に因る損傷

\section{Beitrag zur Radium-und Röntgenschädigung}

\section{des menschlichen Auges.}

Von Dr. med. Heinrich Flaschenträger

Klinische monatsblätter für Augenheil kunde mai-Juni 1924

人眼のラ（「ラデウム」の略）線及びレ（レントグンの略）線によbて起す賃害を

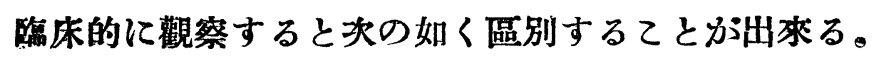

1. 角膜の炎症

2. 水晶體の润濁

3. 緣內障（青々乙と的)

角膜の炎症は一乃至數週間の潜伏期学經て起 万、極めて表在性て輕症の事もある

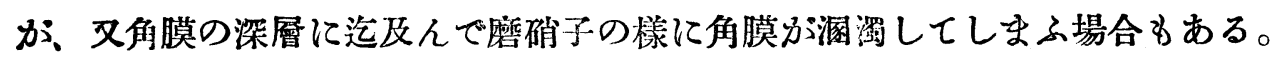

像後は原因を除去すれば大概良好であるが、重鹪にては角膜が破潰されて穿孔す る事るある。1908 年に一年間るラ線及びレ線の照射を受けて息者に眼球結膜（曾 通「しろめ」といふ部) の血管が所々くびれれる太くなれるのを報告しれ人があ る。からる血管の變化はラ線及びレ線による人體組織損鹪の特異にして代表的のる のである。稀に老人に自然に同樣の變狀を呈するてとがあるが容易に區別する事が 出來る。

水晶體の满濁を起す事は最る稀れである。一年、二年又は二年牛る永く光線療法 を行ふと見られる事がある。

綠內障は强力なるレ線照射をなしえる二挒に經驗せる。綠內障とは眼球內糜の上

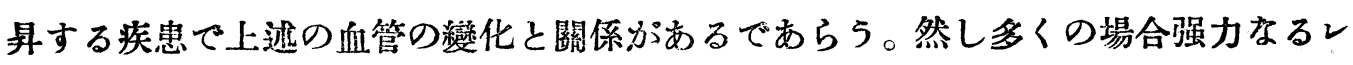
線照射をなすのは眼球に腫物でる出承九場合で、線照射を行はずとる腫物の成長 亲

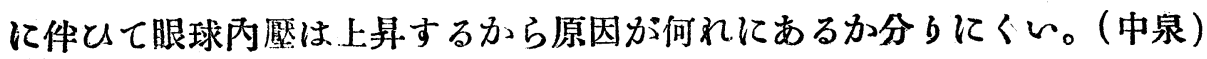




\title{
17. 空に依万書光照明
}

\section{Daylighting from Windows}

\author{
H. H. Higbie and G. W. Younglove
}

(Trans. I. E. S. March, 1924. pp. 235-268)

本交にはミシガン大學工學部に於ける實測並に敎室の模型に就ての試驗の結果を 迅べて居る。その目的は次の如くである。

1. 作業面に達する光束と窥より 万る光束との比即ち人工照明に於りる利用率に相 當するものの最大值、最少值及び本均值を求むる事

2. 作業面に於ける最大照明度と最少照明度との此即台照明の均等度を求むる事

3. 密の外部の情况の種々索る場合に於て空に來る光束密度を求むる事

4. 室の構造特に悹硝子面積と床面積の比苂び空商と室幅又は室長との比が利用率 及び均等度に及济す影響を求さる事

5. 窓の間の仕切入は柱の室內照明に及济す影響を求むる事

以上に就て賏測の表及び圖を揭げ說明を加へてある。

1. 密脚をなさざる空の利用率は 0.46 及び 0.66 の間にある。本均 0.54 となる。

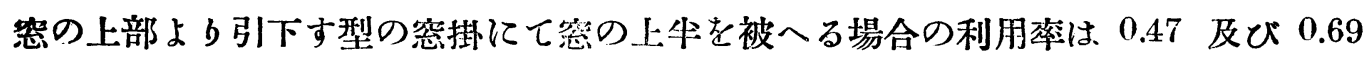
の間にあり本均 0.56 と京る。空の下牛部を被子空掛にありては利用率は 0.33 及 び 0.62 の間にあり本均 0.48 となる。

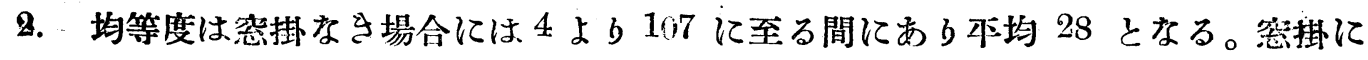
て上牛を被へる場合には 11 と 118 の間に在b本均 49 となる。下牛部を被へる場 合には 6 と 60 の間にあり本均 21 となる。いづれにして子學校照明法案に於て人 工照明の均等度を 4 と規定せるに比して进しく不均等な b。

上牛部を被ふ倠掛を使用すれば室內の最大照明度は空掛なと場合の55 乃至 103 \%、本均して $75 \%$ 亿減じ最少照明度は 14 乃至 $757 \%$ 本均 $41 \%$ に減ず。從て均

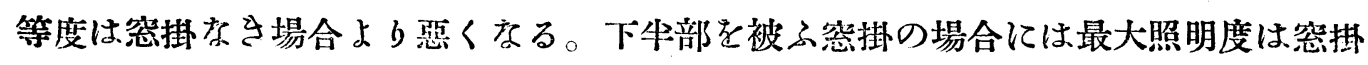
な马場合の 22 乃至 $43 \%$ 本均 $30 \%$ に減じ最少照明度は 43 乃至 $68 \%$ 本均 60 \%に減ずるが故に均等度は良くなる。 


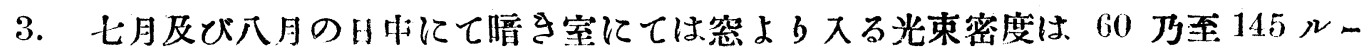

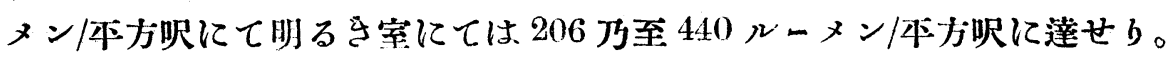

4. (A) 硝工面積と床面積の比が 0.25 以上な礼ば均等度はほ心゙一定の值 15 を保ち ての比が 0.15 以下にては速に均等度が惡くなる。

(B) 空高と室幅の比が 0.6 以上なれば均等度は略一定の值 15 を保ちての比が 0.5 以下となれば均等度が惡くなる。

5. 十分の一の教室模型に就ての試驗の結果に依れば

（A）悹と悹との間の仕切幅のが葖の幅の約 $\frac{1}{4}$ の場合に均等度は最も高く約 6.5 となる。

(B) 利用率子仕切が空の約 $\frac{1}{4}$ の時に最大にて約 $50 \%$ となる。

（C）如何なる場合にて子仕切に依て生ずる照明の不均等は等よb三呎以上の 距離に於ては目にて識別し得ず。仕切に依らて生ずる影の部分の照明度は室の器よ り最も遠さ部分の照明度の少くとも 4 倍に達す。

（D） 空の部分の壁厚 2 呎の時と 3 吋の時とを比較せるに前者に於ては照明度が 後者の $71.5 \%$ に減ずれどす均等度は稍佳となる。

、本交には此他空の上部及下部より入る光束分布の相違、空搟の種類に依る影響、各 種黑板の比較等を論じれb。(尾本義一)

\section{8. ネオン、輝光電球の諸特性}

1. A New Photo-electric and Jonization Effect

$$
\text { U. A. aschwald and A. G. Tarrant pp. 241-252 }
$$

2. On Certain Properties of the "Osglim" Neon Filled Lamp.

J. H. Shaxby and J. C. Evans. pp. 253-261

3. Notes on Some Electrical Properties of the Neon Iamp.

$$
\text { U. A. Oschwald and A. G. Tarrant pp. 262-268 }
$$

4. A Critical Resistance for Flashing of the Low Voltage Neon Discharge Tube.

J. Taylor and W. Clarkson pp. 269-279 
All in Physical Society of Iondon. June 151924

Neon Glow Lamp はネォン死斯を低壓にて充填し鐵製の電極を用とて兩電極間に 一定以上の電壓が加つれ場合に陰極より輝光を發するものである。最もよく使用せ らるつ8のは 100-110 volt 用で 2-3 watt.の電力消費量を有し、電極は任意の形 に作られ得るが故に alphabet を組合はせ諸外國に於て廣告用として使用せられてる る事は占くより文獻に現れてるる。吾々の家庭に於ても之を訾室等に用ふれで極め て妙であら5と思はれる。價格は上記のもの一個に就さ約一圓二十錢見䓨である。

上揭の維誌には是等の8のつ諸特性を物理的方面より細に探究して發表せられて みる。

Neon Glow I amp の輝光を發する電壓は太陽光線、X 線、輻射線等の影響により可 なりの差がある。即ち暗黑に於て 182 volt の笪壓を要するものが之を强す太陽光線 に港す時は輝光發生電壓は 164 volt に低下する。各種の電球を用とて試驗せる結果 は第一表の關係を見る。（筆者が A. E. G 製 100 volt 用のものにつさ試驗せる結 果は輝光發生電娾は 88 volt 乃至 78 volt の範園に變化しれ)。 又 $\mathrm{X}$ 線裝置より の距離により第二表の如き變化がある。

\begin{tabular}{ll}
$\begin{array}{c}\text { 第 } \\
\text { 照 }\end{array}$ 度(吹燭) & $\begin{array}{l}\text { 表 } \\
\text { 輝光發生電疷 } \\
\text { (volt) }\end{array}$ \\
\hline 0 & 182 \\
0.009 & 180.5 \\
0.018 & 175.5 \\
0.023 & 174.0 \\
0.032 & 172.5 \\
0.036 & 171.0 \\
0.072 & 170.4 \\
0.145 & 168.5 \\
0.24 & 167.7
\end{tabular}

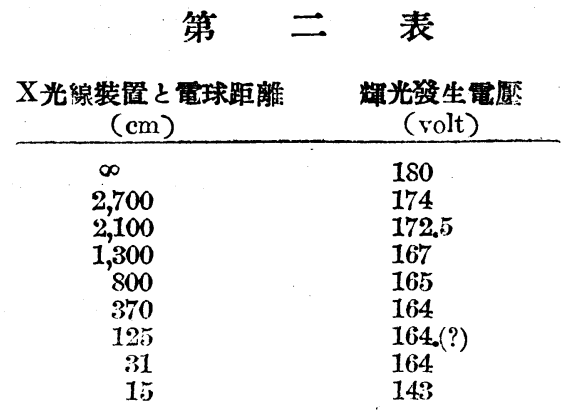

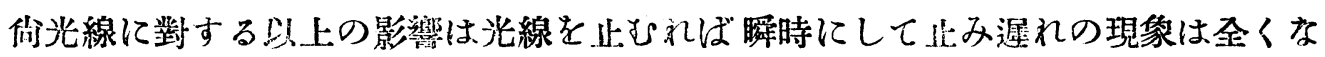

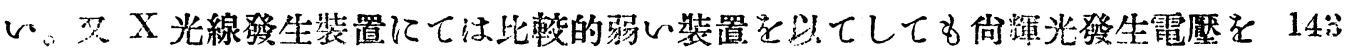
volt に低下せしひる事は極めて容易であつて、この性質を利用して X 光線取报者に 對する危險信號とする事を得。又著者は90 吹を距て、壁其他の障害物を通し小型

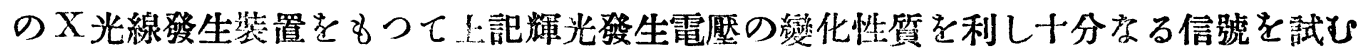
る筆を得れ。

尚電球によつてX光線に對して上記の變化を示す8光線に對しては其性質なっ8 
のありといふ。光線に對して輝光發生電壓の化變を示すものつ電球と然らざるもの との美異につき面白い討諭引゙ある。

(2)の論文に於ては volt-ampere 特性につ马詳細浟表せられてねる。200 volt 交 流にて點火せる場合電厴波の頂點に近く暗點によつて分ねるつ二つの輝點がある。 即電壓波の一周期間に四ヶ所の輝光點があり電壓を次第に低下゙すれば、最初の輝點 續いて最後の輝點方消ゆ最後に殘す二つの輝點の滅するを見る。直流にて回路を閉 づる瞬間にはかや5の現像は京い。最後に著者は任意の艾流を速度の調整の利く整 流子を通じ Neon lamp に供給して其點減回數を勘定して、簡單に供給交流の周波 数を求むる事を述べてるる。

（3）の諭文中著者は電球と蓄電器を並列にしれものを誘導線輪を通じて電池と直 列に接續し、乙の回路に發生する電氣振動を前記線輸に couple しれ二次線輸を通 じて共振回路を作り Radio-transmission の可能性を檢しれか; 95,000 cycle の高周源 迄は得てか゚、電流が小いので目的は達せられなかつね。

份 Neon Glow lamp を Voltage Detector として又は任意の波形の Form Factor を測定する乔に利用し得らるつ事は種々の文獻に見えてるる。(堀岡)。

\section{9. 建筑物纪對与号色箖投射}

\section{Color Fload-Lighting of Building.}

By Arthur V. Gerber and Edwin D. Tillson

Transaction of the Illuminating Engineering Society 1924 July No.6 pp. 518. 526.

本文は米國に於て↔彩投射を行はれれる建物 Mejunkin Building に就さ Gerber 芚び Tillson 氏によりて記述されれるるのにて建物の每本方呎に對する電力消費量 公 の「レコード」を有しているものである。

Arthur U. Gerber 現在に於ける建物は其の色彩を缺除している而し過去各年代に 於て建贸學は其の設計に於て色彩を取入れる事に就て考へてをつれ、古さは埃及希 臘時代より「ルネサンス」時代に到る艺色彩は多く用ひられれが近代に來ては其れ 
を建物の外部に用ふるを止めれ、建物に於て其の外部に色彩を施すに二つの方法が ある其の一つは材料によるものであるが而しててれは其れが破損しれる場合の困難 等の雼めに用こらろれな京つれ、他の方法は塗料を施す方法である、乙れは室內に 於ては種々の氯侯に陾へ得るす外部に對しては全く無效である、英國に於ては「ルネ サンス」時代よb色彩を有する材料を求めてが伊太利、希㜻に於けるが如与材料を得 る事が出來なかつた胥めに其の型は古す Grecian 型となつて單色の石材を用ふる样 になつれ。希臘等の國に於てはてれらの色彩ある材料も屋外に露出し得る氮候であ るが英國其他北歐墸國の気候はてれを許さず、米國に於ても多くの建物は北歐の如 马風に建筑されている、而し近來に到てての風を破らんとする傾向を生じれ、Tillson 氏は光りを應用して此の長い間の望みを滿んしたのである。てれはクリーム色の釉 藥を施しれ Terra cota 上に色彩投射を行及事によつて美し马色彩效果を得るにあ るのである。

Edwin D. Tillson 粗面の Bedford 石又は粗面の花崗岩は其の反射係數は 20 乃至 25\%である。乙の如さ材料で出來ん建物に投射を行ふには先ず其の面を滑けにする 必要がある、今 10,000 本方呎の Bedford 石の面があつて其の反射率を $20 \%$ とす るての建物の面を砂吹さ（Sand-Blasting）を行ふには375 乃至750 弗を要する、而 してての種の建物に粼してはての費用は手頃のものである、Common wealth Edison Buiding は酸で其の表面を洗れれ其の費用は 6,000 弗であつて其の反射係數は $65 \%$ となつれ、滑らかな terra cota の反射係數は６5 乃至 70\% である、種々䐝驗の結 果普通の白色投射を行ふ場合は每本方吹に對して 6 「ワット.|が檤當である、一般 に行はれる投射の方法は町を枮切りて行及るのであるての方法にて投光される建 物は日光の下に在るが如こ建物の特性を發揮せず、而しての投射の方法は現今にて は一般的のものとなつれ、他の投光の方法はてれと同じ如さものであつて 12 吹離 れれる場所より投射するのであるがての場合には建物の蛇腹等の箇所に影を生ずる 又投射を建物自身の蛇腹「ポケット」等上り行及子のがあるがてれは一樣に光りを 投ずる用が出來ずして斑を生ずる、最後に到着しそのが色である即ち色彩と影と光 らである、前述しれるが如さ方然にては壁柱の間に影を生ずる而して色榷投射の場 合には影を生ぜずして或る色の區域を生ず、今用とられれる Mcjunkin Building 
ては蓝色及び綠色の如さるのは約10呎投映され赤色及び琥珀色の如さるのは約50吹

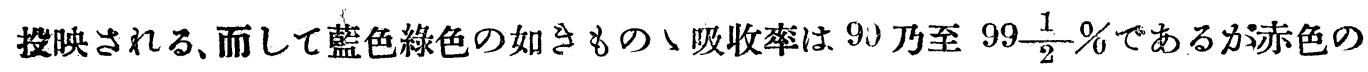
如さすのは 50\% である、是等の色彩を投光されてる建物は非常に美しするのであ る、藍色綠色の投光器に用とられれレンズは熱の篇めに破れれが洏し赤色のものは

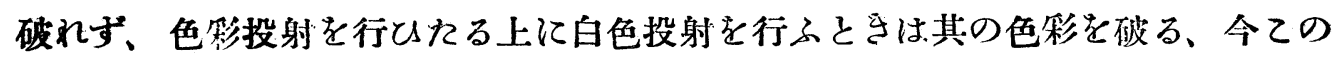
Mcjunkin Building では家の前に 5 個の投光器を 7 吹宛に装置し 2,000「ワット」 を出しれのであるからして每本方吹に11 $\frac{1}{4}$ ワットといふ事になる、今迄用とられれ る白色投光のレコードは10ワットであつて、而し今は $11 \frac{1}{4} に て ミ 40$ 吹全面を照 し得るのである。(門倉则之)

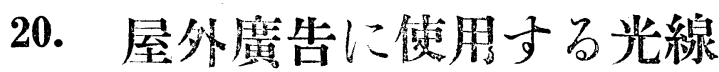

\section{The use of light for Outdoor Advertisement.}

The Illuminating Eng. 1924 April 4. Voll XVIII. p.p. $38-43$.

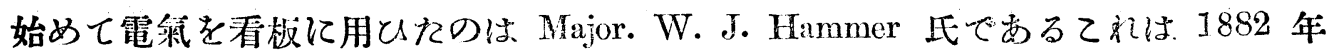
英國の水晶宮の萬國博覽會に於て行はれたのである而しててれは屋內に設けられれ すのであるが其㷋同氏により伯林の Health 博覽會に於て始めて屋外のものが設け られれてのとさに用しられれ方法は現今用でられている方法の全部を包括していれ のである。電氣看饭の發達は參くは白熱電球の發達によるものである、英國に於て 始めて用ひられれ運動するィルミネーションは “Flasher”といふ型のものであつ

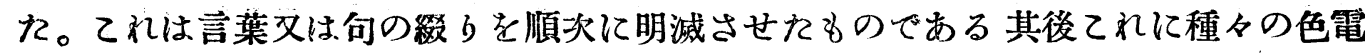
球を用汸れ、米國に於けるるのはてれと異なる大なる文字を出來るだけ多くの電燈 言 にて作 b全部を一度に開閉器によりて明隇させるものである、今各項目に分けて考 ヘて見ると

構造 初期のものは本面型（Flush type）と云はれるすのであつて本坦な背景の むのが用とられれてれは或る色に染れてあつて其の上に電球を交字の形に配列しれ 
ものであるてれは種々の解度よるして其の文字を讀さ事は困難である、次に用とら れれのは個々別々に離れれ文字を用とれるのであるがてれる種々の缺點を有す、乙 の文字は始めのものは木で作れるのを Bayont ホルダーと共に用とれが其後金屬製 の交子を陶器製の特別なホルダーと共に用しる事によつて狳程缺點は少なくなつれ、 最近に用とられている交字の形は葉鐵を用てれ溝型斷面のもので電球のホルダーは エデソン、スクリュー、電球に合及陶器製のものが用とられる。

電球 電氣看栃の長足の發達は金屬纎條電球の發達に大いに關係がある現今用と られている看板の廻轉する車又は運動する動物等の活動するものは台い炭素電球で は其の目的を達する事は出承收のである、乙の方法は或る電球を早く開閉する事に 依て行ひ得るのである、米國に於てはての方法に對して非常に研究され種々の翼れ 問題に適倠するが如さ多くの電燈を有する板を製作するに到れ、最近ある米國の技 術者は或る定せつた距離よらして個々の電球の特性に對して研究しれ其の結果に依 れば電球は蛋白色にするか义は透明なェナメルを塗りれるものがよさ結果を與へる と云及事を發表しれ、ヌ一般電球に對して種々研究されているが其の必要條件は丈 夫、長壽命、少なる形狀、先端の燭光大なる事、及び無 kip 等である、色彩は非常 に必要のものであつててれを得る篇めに種々の方法が行はれれ、始期に用にられれ る方法は色硝子を用とれるのとニスを鉒るものの二つであつれ、而し色硝子球を用 ふるは其の價格の高くするれめに用とられなかつれ丈ニスを塗るるのは天候に弱さ 営めに用とられなかつれ、其後に用とられれものは自然色の被とを普通の電球に覆 せるものであつれ、最近に到つて書光色電燈を用及樣になつれてれは普通電球、无 斯封入電球共に用とられ特に 後者は其の高度の杵さのれめに重要なるのとなつれ、 今日用ひられているものはての瓦斯入のものをエナメルで色彩を施しれるのであつ てての結果は他のものより稌程よとのである、而しエナメルは大なる吸集率を有す ものである、故に大なる電球を使用する場合には其の電流消費量を考々る必要あり。

開閉器 電氯看板の活動型のものの最も重要なるものは Flasher であるてれを得 るに必要なるものは接触刷子と制御器である、開閉の效果は各々の機構の速度によ るのである。

制限 電氯看板に對する制限は各國又各都市によりて種々異なる一定してい好る 
のである。

今電氯看板の發達しれ理由を大别すれば次の如さものである。

1. 人の注意を得る性質を有す

2. 讀れ易与事

范販項力

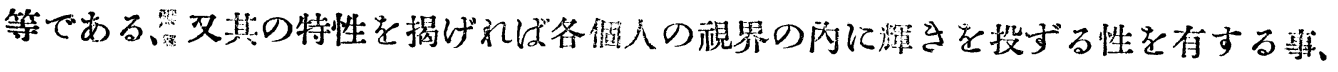

速動する物體を表す事、其の色彩の自由及び如何京る場所にも設け得られる事等で ある。(門倉) 